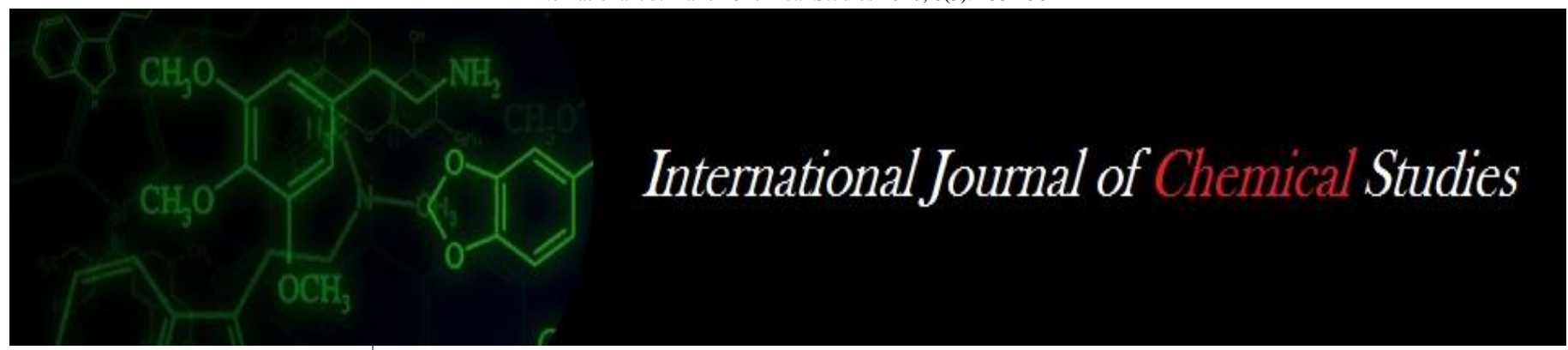

P-ISSN: 2349-8528

E-ISSN: 2321-4902

www.chemijournal.com

IJCS 2020; 8(3): 455-458

(C) 2020 IJCS

Received: 25-03-2020

Accepted: 26-04-2020

Majid Rashid

Division of Vegetable Science, Sher-e-

Kashmir University of Agricultural Scienc

and Technology of Kashmir, Shalimar,

Srinagar, Jammu and Kashmir, India

KP Wani

Division of Vegetable Science, Sher-e-

Kashmir University of A aricultural Scienc

Te

K Hussain

Division of Vegetable Science, Sher-e-

Kashmir University of Agricultural Science

and Technology of Kashmir, Shalimar,

Srinagar, Jammu and Kashmir, India

\section{ZA Dar}

Division of Genetics and Plant Breeding,

Sher-e-Kashmir University of Agricultural

Sciences and Technology of Kashmir,

Shalimar, Srinagar, Jammu and Kashmir,

India

\section{PK Singh}

Division of Vegetable Science, Sher-e-

Kashmir University of Agricultural Sciences

and Technology of Kashmir, Shalimar,

Srinagar, Jammu and Kashmir, India

\section{Aroosa Khalil}

Division of Fruit Science, Sher-e-Kashmir

University of Agricultural Sciences and

Technology of Kashmir, Shalimar, Srinagar,

Jammu and Kashmir, India

Gowhar Ali

Division of Genetics and Plant Breeding, Sher-e-Kashmir University of Agricultural Sciences and Techulogy of $\mathrm{K}$ a hir. Stiences and Technology of Kashmir,

Syeda Farwah

Division of Vegetable Science, Sher-eKashmir University of Agricultural Science and Technology of Kashmir, Shalimar, Srinagar, Jammu and Kashmir, Indi

\section{Syed Mazahir Hussain}

Division of Vegetable Science, Sher-e-

Kus

Kashmir Univesity of Agicultural Scie

and Technology of Kashmir, Shalimar,

Srinagar, Jammu and Kashmir, India

Seerat Rizvi

Division of Vegetable Science, Sher-e-

Kashmir University of Agricultural Sciences

and Technology of Kashmir, Shalimar,

Srinagar, Jammu and Kashmir, India
Corresponding Author:

Majid Rashid

Division of Vegetable Science, Sher-eKashmir University of Agricultural Sciences and Technology of Kashmir, Shalimar, and Technology of Kashmir, Shalimar,

\section{Studies on genetic variability, heritability and genetic advance in bottle gourd [Lagenaria siceraria (Molina) Standl.] genotypes}

\author{
Majid Rashid, KP Wani, K Hussain, ZA Dar, PK Singh, Aroosa Khalil, \\ Gowhar Ali, Syeda Farwah, Syed Mazahir Hussain and Seerat Rizvi
}

DOI: https://doi.org/10.22271/chemi.2020.v8.i3e.9253

\begin{abstract}
The present investigation was carried out at the Experimental Field, Division of Vegetable Science, SKUAST-K, Shalimar during Kharif 2018. The experiment was laid out in randomized complete block design (RCBD) with three replications. Thirty genotypes were evaluated for various quantitative and quality traits. Analysis of variance revealed significant differences among genotypes for all the traits. The estimates of phenotypic coefficient of variance were slightly higher than the corresponding genotypic coefficient of variance for all the characters studied indicating the little influence of environment in the expression of these traits. The highest phenotypic and genotypic coefficients of variation were observed for fruit diameter (35.65 and 34.62) followed by total chlorophyll (30.08 and 20.02) and fruit length (23.70 and 23.44). High heritability coupled with high genetic advance was recorded for fruit length (0.97 and 47.74), fruit diameter (0.94 and 71.73), total sugars (0.74 and 24.05) and dry matter content ( 0.84 and 25.42) indicating that the heritability is most likely due to additive gene effects and thus the chances of fixing by selection are more.
\end{abstract}

Keywords: Genetic variability, heritability, Lagenaria siceraria

\section{Introduction}

Bottle gourd [Lagenaria siceraria (Molina) Standl.] $(2 \mathrm{n}=2 \mathrm{x}=22)$ belongs to family Cucurbitaceae and is one of the most ancient crop cultivated during summer throughout the world. The genus Lagenaria is derived from the word lagena, meaning the bottle. It is also known as Calabash, Doodhi and Lauki in different parts of India (Deore et al., 2009) ${ }^{[4]}$. Itsprimary centre of origin is Africa (Singh, 1990) ${ }^{[22]}$. The genus Lagenaria includes six species that are distributed in Africa, Madagascar, Indo-Malaysia and the neotropics. There is only one cultivated species, Lagenaria siceraria, which is annual and monoecious. The five other species are wild, perennial and dioecious, occurring in East Africa and Madagascar. It has a good amount of vitamins and minerals. Its fruit contains 95.54\%moisture, vitamin C $(10.1 \mathrm{~g})$, vitamin A (16 IU), thiamine $(0.029 \mathrm{~g})$, riboflavin $(0.022 \mathrm{~g})$, niacin $(0.320 \mathrm{~g})$, carbohydrates $(3.39 \mathrm{~g})$, fats $(0.02 \mathrm{~g})$ and potassium $(150 \mathrm{mg}) / 100 \mathrm{~g}(\mathrm{USDA}, 2018)^{[25]}$. It is ideal for human food or for incorporation into livestock feed (Ogunbusola et al., 2010) ${ }^{[14]}$. It is easily digestible and is therefore recommended during convalescence. The dietary fiber present in the bottle gourd makes it a very useful vegetable in preventing digestive disorders such as constipation. A positive correlation has been found between fiber consumption and the reduction of coronary heart diseases and diabetes incidence (Hemeda et al., 2008) ${ }^{[8]}$. Bottle gourd juice is used traditionally as a medicine for treating acidity, indigestion and ulcers besides being a good thirst quencher. The fruit is found to be antidote to certain poisons and scorpion stings, and also has purgative and cooling effects. The fruit is believed to have ability to relieve pain and is effective against fever, and hence found useful in treatment of asthma and other bronchial disorders. It is also a good source of natural antioxidants (Deore et al., 2009) ${ }^{[4]}$. It helps in losing weight quickly, because of its high dietary fiber and low fat and cholesterol content (Parle and Kaur, 2011) ${ }^{[17]}$. A decoction made from leaves acts as medicine for curing jaundice. It has a cooling property. During hot season, the cut surface of small sized fruit is rubbed on the flat of the feet and hand to diminish the effect of heat. 
The seeds are rich in essential amino acids, minerals, lipids and fatty acids (Essien et al., 2013) ${ }^{[5]}$ and are also used for oil extraction. The fatty acid profile shows linoleic acid as the most abundant (62\%) as compared to oleic (16.2\%), palmitic $(14.4 \%)$ and stearic $(5.8 \%)$ acids. High linoleic and low linolenic acid levels of these oils suggest that they could be sources of good edible oils for cooking. The abundance of linoleic acid followed by oleic acid in bottle gourd seed makes them good oils for reducing serum cholesterol and low density lipoprotein (LDL) and increasing high density lipoprotein (HDL) levels, hence, they could be good oils to fight against cardiovascular illnesses (Fokou et al., 2009) ${ }^{[6]}$. Dry hard shells of the fruits have been used for making a wide range of articles of common use, including bowls, bottles, containers, floats for fishing nets and musical instruments (Wikipedia, 2018) $^{[26]}$.

\section{Materials and methods}

The present investigation was carried out at Vegetable Experimental Farm, Division of Vegetable Science, SKUAST-Kashmir, Shalimar, Srinagar during Kharief 2018. The altitude of the location is 1685 meter above mean sea level and situated $34^{\circ} \mathrm{N}$ of latitude and $74.89^{\circ} \mathrm{E}$ of longitude. The climate is temperate characterized by mild summers. The mean minimum and maximum temperatures are recorded in months of January and June (respectively). The maximum rain fall is received during March to April. Thirty genotypes of bottle gourd were evaluated for various yield and yield attributing traits. A single factor experiment was laid out in randomized complete block design (RCBD) with three replications of each accession per plot. Plants from each genotype were transplanted at random to each block at spacing of $1 \mathrm{~m}$ between rows and $0.60 \mathrm{~m}$ between plants. Recommended package of practices were adopted to raise a healthy crop. The observations were recorded on node number at which first male flower appeared, node number at which first female flower appeared, days to anthesis of first male flower, days to anthesis of first female flower, days to first fruit harvest, days to last fruit harvest, fruit length, fruit diameter, number of fruits plant ${ }^{-1}$, fruit yield plant $^{-1}$, fruit yield hectare ${ }^{-1}$, dry matter content, total chlorophyll and total sugars. The analysis of variance was done as per procedure described by Panse and Sukhatme (1957) ${ }^{[16]}$. The magnitude of phenotypic co-efficient of variation (PCV) and genotypic co-efficient of variation (GCV) existing in a trait was worked out by the formula given by Burton (1952) ${ }^{[1]}$. PCV and GCV were categorized as low, moderate and high by following Sivasubramanian and Menon (1973) as $(0-10 \%)$ : Low, $(10-$ 20\%): Moderate, (Above 20\%): High respectively. Heritability in broad sense was estimated as per the procedure presented by Burton and Devane (1953) ${ }^{[2]}$. The heritability percentage was categorized as low, moderate and high as suggested by Robinson et al. (1949) ${ }^{[20]}$ (0-30\%): Low, (30$60 \%)$ : Moderate and (60\% and above): High respectively. Genetic advance at 5 per cent selection intensity was worked out by using the formula given by Lush (1949) ${ }^{[11]}$ and Johnson et al. $(1955)^{[10]}$. The Genetic advance as per cent of mean was categorised as low, moderate and high by following Johnson et al. (1955) ${ }^{[10]}$ (0-10\%): Low, (10-20\%): Moderate and (Above 20\%): High respectively.

\section{Results and discussion}

In the present study, thirty genotypes of bottle gourd were evaluated to estimate the genetic variability, heritability and genetic advance (as percent of mean). The range in the values reflect the amount of phenotypic variability, which is not very reliable since it includes genotypic, environmental and genotype $\times$ environmental interaction components and does not reveal as to which character is showing higher degree of variability. Further, the phenotype of crop is influenced by additive gene effect (heritable), dominance (non-heritable) and epistasis (no allelic interaction). Hence, it becomes necessary to split the observed variability into phenotypic coefficient of variation and genotypic coefficient of variation, which ultimately indicates the extent of variability existing for various traits.

The analysis of variance revealed that all the characters exhibited highly significant differences among the genotypes (Table-1). The estimates of phenotypic and genotypic coefficients of variation of all the characters studied are presented (Table-2). In general the phenotypic and genotypic coefficients of variation were almost similar with slight higher phenotypic coefficients of variation, which indicates the role of environment in the expression of traits under observation. This was in agreement with the study of Mathew et al. (2001), Chowdhary and Sharma, (2002), Ram et al. (2005) and Husna et al. (2011) ${ }^{[21,3,19,9]}$. It is evident from the data (Table-2) that fruit length (23.43 and 23.16), fruit diameter (35.65 and 34.62) and total chlorophyll (30.08 and 20.02) recorded high phenotypic and genotypic coefficients of variation respectively, indicating that genotypes had broad genetic base for these characters. Rest of the traits such as total sugars (15.62 and 13.50), dry matter (14.57 and 13.41), node number at which first female flower appeared (12.14 and 9.68), node number at which first male flower appeared (8.26 and 5.63), number of fruits plant $^{-1}(6.96$ and 5.46), days to anthesis of first male flower (6.62 and 6.24), days to anthesis of first female flower (5.77 and 5.11), fruit yield plant ${ }^{-1}$ (4.21 and 3.18 ), fruit yield hectare ${ }^{-1}(4.29$ and 3.33$)$, days to first fruit harvest (2.99 and 2.68) and days to last fruit harvest (2.83 and 2.57) showed moderate to low phenotypic and genotypic coefficients of variation respectively. Thus these characters were less amenable for improvement through selection. This was in conformity with findings of Rahman et al.(1986), Chowdhury and Sharma (2002), Singh and Kumar (2002), Munshi and Acharyya (2005), Gayen and Hossain (2006), Yadav et al.(2008), Pandit et al. (2009) and Husna et al. (2011) $[18,3,22,13,7,27,15,9]$. Characters which possessed moderate to high coefficients of variation suggested that there is better potential for improvement through selection. A wide range of variability along with high estimates of phenotypic and genotypic coefficients of variation further indicate that these attributes would respond to selection. Even phenotypic and genotypic coefficients of variation does not give a true picture about the extent of inheritance of the character. Therefore, the heritability of a character can be relied upon, as it enables the breeder to decide the extent of selection pressure to be applied under a particular environment, which separates out the environmental influence from the total variability. The estimation of heritability has a greater role to play in determining the effectiveness of selection of a character provided it is considered in conjunction with the predicated genetic advance as suggested by Panse and Sukhatme (1957) ${ }^{[16]}$ and Johnson et al. (1955) ${ }^{[10]}$ as heritability is influenced by bio-metrical method, generation of hybrid, sample size of experimental material and environment. Furthermore the progress in selection is also directly proportional to the amount of genetic advance. Therefore, the effect of selection is realized more quickly in those characters which have high heritability as well as high 
genetic advance. The relative amount of heritable portion of variation was, therefore, estimated with the help of heritability estimates and genetic advance. When high heritability is accompanied with high genetic advance (as per cent of mean), it indicates additive gene effects and selection may be effective. High heritability with low genetic advance indicates importance of non-additive gene action where high heritability is exhibited due to favourable influence of environment rather than genotype and the selection for such traits may not be rewarding. Low heritability with high genetic advance is governed by additive gene effects in which low heritability is exhibited due to high environmental effects and the selection may be effective in such cases. Low heritability coupled with low genetic advance indicates that character is highly influenced by environmental effects and selection would be ineffective. Heritability (b.s) estimates were high for almost all the characters except node number at which first male flower appeared, number of fruits plant ${ }^{-1}$, fruit yield plant ${ }^{-1}$, fruit yield hectare ${ }^{-1}$, total chlorophyll and ranged from 44 to 97 per cent indicating that the characters are less influenced by environmental effects and the characters are effectively transmitted to the progeny, suggesting major role of genetic constitution in the expression of a character and thus selection based on phenotypic expression could be relied upon. Similar results were also reported by Sharma et al. (2010) ${ }^{[21]}$ who observed moderate heritability for female flowering node and low heritability for days to first harvesting. High estimate of heritability along with genetic advance (as per cent of mean) is more reliable than heritability alone for predicting the effect of selection (Johnson et al., 1955) ${ }^{[10]}$. The characters viz., fruit length, fruit diameter, total sugars, and dry matter content showed high estimates of heritability coupled with high genetic advance (as per cent of mean), indicating the preponderance of additive gene action for control of these traits. This suggests that real progress in improvement through selection could be made for yield. Similar results were reported by Singh and Kumar (2002) ${ }^{[22]}$ for fruit length, fruit diameter, fruit weight plant ${ }^{-1}$ and fruit yield plant ${ }^{-1}$, Gayen and Hossain (2006) ${ }^{[8]}$ for number of primary branches plant ${ }^{-1}$, number of days to first male flower anthesis, number of days to first female flower anthesis, fruit length, fruit weight, number of fruits plant $^{-1}$, fruit yield plant $^{-1}$. Similar results were also reported by Rahman et al. (1986) and Munshi and Acharyya $(2005)^{[18,13]}$.

Table 1: Analysis of variance with respect to MSS for various characters in bottle gourd.

\begin{tabular}{|c|c|c|c|c|c|c|c|c|}
\hline \multirow[b]{2}{*}{$\begin{array}{l}\text { Source of } \\
\text { variation }\end{array}$} & \multirow[b]{2}{*}{ d.f } & \multicolumn{7}{|c|}{ Mean sum of squares } \\
\hline & & $\begin{array}{l}\text { Node no. at which } \\
\text { first male flower } \\
\text { appeared }\end{array}$ & $\begin{array}{c}\text { Node no. at which } \\
\text { first female flower } \\
\text { appeared }\end{array}$ & $\begin{array}{c}\text { Days to anthesis } \\
\text { of first male } \\
\text { flower }\end{array}$ & $\begin{array}{l}\text { Days to anthesis } \\
\text { of first female } \\
\text { flower }\end{array}$ & $\begin{array}{l}\text { Days to first } \\
\text { fruit harvest }\end{array}$ & $\begin{array}{c}\text { Days to last } \\
\text { fruit harvest }\end{array}$ & $\begin{array}{c}\text { Fruit } \\
\text { length }(\mathrm{cm})\end{array}$ \\
\hline Replication & 2 & 0.0057 & 0.29 & 1.99 & 5.39 & 2.20 & 3.06 & 23.85 \\
\hline Genotypes & 29 & $0.73 * *$ & $3.73 * *$ & $24.50 * *$ & $22.16^{* *}$ & $10.99 * *$ & $45.64 * *$ & $573.54 * *$ \\
\hline Error & 58 & 0.20 & 0.59 & 0.99 & 1.86 & 0.82 & 3.02 & 4.34 \\
\hline
\end{tabular}

Contd: Table-1

\begin{tabular}{|c|c|c|c|c|c|c|c|c|}
\hline \multirow[b]{2}{*}{$\begin{array}{l}\text { Source of } \\
\text { variation }\end{array}$} & \multirow[b]{2}{*}{ d.f } & \multicolumn{7}{|c|}{ Mean sum of squares } \\
\hline & & $\begin{array}{c}\begin{array}{c}\text { Fruit diameter } \\
(\mathrm{cm})\end{array} \\
\end{array}$ & $\begin{array}{c}\text { No. of fruits } \\
\text { plant }^{-1}\end{array}$ & $\begin{array}{l}\text { Fruit yield } \\
\text { plant }^{-1}(\mathrm{~kg})\end{array}$ & \begin{tabular}{|c|}
$\begin{array}{c}\text { Total sugars } \\
(\%)\end{array}$ \\
\end{tabular} & $\begin{array}{c}\text { Total Chlorophyll } \\
\left(\mathrm{mg100g}^{-1}\right)\end{array}$ & $\begin{array}{l}\text { Dry matter } \\
\text { content }(\%)\end{array}$ & $\begin{array}{c}\text { Fruit yield } \\
\left(\text { qha }^{-1}\right)\end{array}$ \\
\hline Replication & 2 & 0.06 & 0.09 & 0.06 & 0.02 & 132.55 & 0.008 & 1704.98 \\
\hline Genotypes & 29 & $9.59 * *$ & $0.31 * *$ & $0.16^{* *}$ & $0.15 * *$ & $333.38 * *$ & $2.03 * *$ & $4457.42 * *$ \\
\hline Error & 58 & 0.18 & 0.05 & 0.02 & 0.01 & 98.40 & 0.11 & 807.76 \\
\hline
\end{tabular}

*,**-Significant at $5 \%$ and $1 \%$ level of significance respectively

Table 2: Estimates of Genetic Variability parameters for various quantitative and quality characters in bottle gourd.

\begin{tabular}{|c|c|c|c|c|c|c|c|c|c|}
\hline $\begin{array}{c}\text { S. } \\
\text { No. }\end{array}$ & Parameters & Mean & Range & $\begin{array}{c}\text { Phenotypic } \\
\text { variance (PV) }\end{array}$ & $\begin{array}{c}\text { Genotypic } \\
\text { variance } \\
(\mathbf{G V}) \\
\end{array}$ & $\begin{array}{c}\text { Phenotypic } \\
\text { coefficient of } \\
\text { variation }(\mathrm{PCV})\end{array}$ & \begin{tabular}{|c|} 
Genotypic \\
coefficient of \\
variation (GCV) \\
\end{tabular} & $\begin{array}{c}\text { Heritability } \mathbf{h}^{2} \\
\text { (broad sense) }\end{array}$ & $\begin{array}{c}\text { Genetic } \\
\text { advance (as } \\
\% \text { of mean) } \\
\end{array}$ \\
\hline 1. & $\begin{array}{c}\text { Node no. at which } \\
\text { first male flower } \\
\text { appeared }\end{array}$ & 7.44 & $6.26-8.33$ & 0.37 & 0.17 & 8.26 & 5.63 & 0.46 & 7.90 \\
\hline 2. & $\begin{array}{c}\text { Node no. at which } \\
\text { first female flower } \\
\text { appeared }\end{array}$ & 10.56 & $\begin{array}{l}7.13- \\
12.00\end{array}$ & 1.64 & 1.04 & 12.14 & 9.68 & 0.63 & 15.91 \\
\hline 3. & $\begin{array}{l}\text { Days to anthesis of } \\
\text { first male flower }\end{array}$ & 44.86 & $\begin{array}{l}41.53- \\
51.33 \\
\end{array}$ & 8.83 & 7.83 & 6.62 & 6.24 & 0.88 & 12.11 \\
\hline 4. & $\begin{array}{l}\begin{array}{l}\text { Days to anthesis of } \\
\text { first female flower }\end{array} \\
\end{array}$ & 50.86 & $\begin{array}{l}46.80- \\
56.66 \\
\end{array}$ & 8.62 & 6.76 & 5.77 & 5.11 & 0.78 & 9.33 \\
\hline 5. & \begin{tabular}{|c|}
$\begin{array}{c}\text { Days to first fruit } \\
\text { harvest }\end{array}$ \\
\end{tabular} & 68.64 & $\begin{array}{l}66.20- \\
75.73 \\
\end{array}$ & 4.21 & 3.38 & 2.99 & 2.68 & 0.80 & 4.95 \\
\hline 6. & $\begin{array}{c}\text { Days to last fruit } \\
\text { harvest }\end{array}$ & 146.35 & $\begin{array}{l}140.33- \\
154.46 \\
\end{array}$ & 17.23 & 14.20 & 2.83 & 2.57 & 0.82 & 4.81 \\
\hline 7. & Fruit length $(\mathrm{cm})$ & 59.45 & $\begin{array}{c}25.06- \\
74.53 \\
\end{array}$ & 194.07 & 189.73 & 23.43 & 23.16 & 0.97 & 47.74 \\
\hline 8. & Fruit diameter $(\mathrm{cm})$ & 5.11 & $\begin{array}{l}4.01- \\
10.88 \\
\end{array}$ & 3.32 & 3.13 & 36.91 & 35.85 & 0.94 & 71.73 \\
\hline 9. & No. of fruits plant ${ }^{-1}$ & 5.18 & 4.01-6.9 & 0.13 & 0.08 & 10.96 & 8.64 & 0.62 & 14.02 \\
\hline 10. & $\begin{array}{c}\text { Fruit yield plant }^{-} \\
{ }^{1}(\mathrm{~kg})\end{array}$ & 6.28 & $4.32-7.57$ & 0.07 & 0.04 & 7.45 & 5.77 & 0.60 & 9.22 \\
\hline
\end{tabular}




\begin{tabular}{|c|c|c|c|c|c|c|c|c|c|}
\hline 11. & Total sugars (\%) & 1.60 & $1.16-2.00$ & 0.06 & 0.04 & 15.62 & 13.50 & 0.74 & 24.05 \\
\hline 12. & $\begin{array}{c}\text { Total Chlorophyll } \\
\left(\mathrm{mg}_{\left.100 \mathrm{~g}^{-1}\right)}\right.\end{array}$ & 44.19 & $\begin{array}{c}25.27- \\
65.25\end{array}$ & 176.73 & 78.32 & 30.08 & 20.02 & 0.44 & 27.46 \\
\hline 13. & $\begin{array}{c}\text { Dry matter } \\
\text { content (\%) }\end{array}$ & 5.96 & $3.86-7.20$ & 0.75 & 0.64 & 14.57 & 13.41 & 0.84 & 25.42 \\
\hline 14. & Fruit yield (qha $\left.{ }^{-1}\right)$ & 1046.36 & $\begin{array}{c}720.53- \\
1261.06\end{array}$ & 2024.32 & 1216.55 & 7.45 & 5.77 & 0.60 & 9.22 \\
\hline
\end{tabular}

\section{Conclusion}

It is clear from the above discussion that tremendous potential exists for converging the elite allelic resources present in these bottle gourd genotypes through a systematic breeding and selection approach so as to recover high yielding recombinants, with good quality characteristics. Analysis of variance revealed that significant variation existed among various characters under study. Fruit length, fruit diameter and total chlorophyll recorded high phenotypic and genotypic coefficients of variation respectively, indicating that the genotypes had broad genetic base for these characters. High heritability coupled with high genetic advance (as per cent of mean) was observed for fruit length, fruit diameter, total sugars and dry matter content indicating the preponderance of additive gene action.

\section{References}

1. Burton GW. Quantitatve inheritance in grasses. Proceedings of $6^{\text {th }}$ International Grassland congress.1952; 11:277-283.

2. Burton GW, Devane CH. Estimating heritability in tall fescue (Festuca arundinacea) from replicated clonal material. Agronomy Journal. 1953; 45:478-481.

3. Chowdhury D, Sharma KC. Studies on variability, heritability, genetic advance and correlation in ridge gourd. Horticultural Journal. 2002; 15(3):53-58.

4. Deore SL, Khadabadi SS, Patel QR. In vitro antioxidant activity and quantitative estimation of phenolic content of Lagenaria siceraria. Rasayan Journal of Chemistry. 2009; 2(1):129-132.

5. Essien EE, Antia BS, Peter NUS. Lagenaria siceraria (Molina) Standl. properties of seed oils and variability in fatty acids composition of ten cultivars. International Journal of Natural Products Research. 2013; 3:102-106.

6. Fokou E, Achu BM, Kansci G, Ponka R, Fotso M, Tchiegang $\mathrm{C}$ et al. Chemical properties of some Cucurbitaceae oils from Cameroon. Pakistan Journal of Nutrition. 2009; 8:1325-1334.

7. Gayen N, Hossain M. Study of heritability and genetic advance in bottle gourd [Lagenaria siceraria (Molina) Standl.]. Journal of Interacademicia. 2006; 10(4):463466.

8. Hemeda HM, Ibrahim HS, Khattab HAH. Bakery fortification and biological evaluation of bottle gourd seeds (Lagenaria siceraria). Egyptian Journal of Food Science. 2008; 36(1):93-113.

9. Husna A, Mahmud F, Islam MR, Mahmud MAA, Ratna M. Genetic variability correlation and path coefficient in Bottle gourd [Lagenaria siceraria (Molina) Standl.]. Advance in Biological Research. 2011; 5(6):323-327.

10. Johnson HW, Robinson HF, Comstock RE. Estimates of genetic and environmental variability in soybean. Agronomy Journal. 1955; 47:314-318.

11. Lush JL. Heritability of quantitative characters in farm animals. Proceedings of the $8^{\text {th }}$ International Congress on Genetics. Genetics Supliment. Heredits, 1949, 356-395.
12. Mathew A, Markose BL, Rajan S, Devi SN. Genetic divergence in bottle gourd [Lagenaria siceraria (Molina) Standl.] Vegetable Science. 2001; 28(2):121-123.

13. Munshi R, Acharya P. Varietal evaluation in bottle gourd genotypes. Indian Journal of Agricultural Research. 2005; 49(3/4):213-221.

14. Ogunbusola M, Fagbemi T, Osundahunsi O. Amino acid composition of Lagenaria siceraria seed flour and protein fractions. Journal of Food Science and Technology. 2010; 47:656-661.

15. Pandit MK, Mahato B, Sakar A. Genetic variability heritability and genetic advance for some fruit characters and yield in bottle gourd [Lagenaria siceraira (Molina.) Standl.]. Acta Horticulturae. 2009; 809:(221223).

16. Panse VG, Sukhatme PV. Statistical methods for agricultural workers. Indian Council of Agricultural Research, New Delhi, 1957, 157-165.

17. Parle M, Kaur S. Is bottle gourd a natural gourd? International Research Journal of Pharmacy. 2011; 2(6):13-17.

18. Rahman AKMM, Das MK, Haque MM. Variability, correlation and path co-efficient analysis in bottle gourd [Lagenaria siceraria (Molina) Standl.]. Bangladesh Journal of Agriculture. 1986; 11(3):13-20.

19. Ram D, Rai M, Verma A, Singh Y. Genetic variability and association analysis in Luffa species. Indian Journal of Horticulture. 2005; 63(3):294-297.

20. Robinson HF, Comstock RE, Harvey PH. Estimation of heritability and degree of dominance in corn. Journal of Agronomy. 1949; 4:353-359.

21. Sharma N, Sharma NK, Malik YS. Estimation of genetic variation in bottle gourd. Haryana Journal of Horticulture Sciences. 2010; 39(3-4):313-315.

22. Singh DK, Kumar R. Studies on the genetic variability in bottle gourd. Progressive Horticulture. 2002; 34(1):99101.

23. Singh AK. Cytogenetics and evolution in the cucurbitaceae. Cornell University, London, 1990, 10-28.

24. Sivasubramanian J. Madhavamenon P. Genotypic and phenotypic variability in rice. Madras Agricultural Journal. 1973; 12:15-16.

25. USDA. National Nutrient Database for Standard Reference, release 1. The national agricultural library, 2018. https://ndb.nal.usda.gov/ndb/.

26. Wikipedia. Cultural uses of bottle gourd, 2018. https://en.wikipedia.org/wiki/ Calabash

27. Yadav JR, Yadav A, Srivastava JP, Mishra G, Parihar NS, Singh PB. Study on variability, heritability and genetic advance in bottle gourd [Lagenaria siceraria (Molina) Standl.]. Progressive Research. 2008; 3(1):7072. 